Article

\title{
Mediated Psychopathy-A Critical Discourse Analysis of Newspaper Representations of Aggression
}

\section{Roland Paulsen}

$\mathrm{W}$ hen concepts such as "terrorism," "fanaticism" and "extremism" proliferate epidemically among the popular explanations of human aggressiveness, bluntly exposing their inherent hollowness, other concepts stay in the background, influencing, without necessarily being mentioned, our view of aggressiveness. Psychopathy is such a concept, and its pretensions to explain are quite extraordinary. "Psychopaths make up a significant portion of the people the media describe," the world-leading expert on psychopathy (or at least the most quoted one), Hare, asserts:

Serial killers, rapists, thieves, swindlers, con men, wife beaters, white-collar criminals, abusers, gang members, disbarred lawyers, drug barons, professional gamblers, members of organized crime, doctors who've lost their licenses, terrorists, cult leaders, mercenaries and unscrupulous business people $[\ldots]$ Read the newspaper in this light [i.e. in the light of the theory of psychopathy] and the clues to the extent of the problem virtually jump off the page. ${ }^{1}$

This advice of Hare has lately been taken seriously in mass media. Given the skepticism with which the concept of psychopathy has been treated earlier, and given the lack of substantial change regarding both the diagnosis (identification of the disease) and the aetiology (what is considered to cause the disease), the revival of the concept deserves some discussion.

In 1947 the Swedish psychiatrist Gerle asserted the bankruptcy of the concept of psychopathy: "This concept is like the emperor's new clothes, it is a nothing."' 2 Before World War II, a biological model of aggression and especially deviant aggression dominated. The concept of psychopathy, which explains aggressive behavior as rooted in the individual's biology (earlier in shape of the skull, bodily fluids, blood etc. and nowadays in genes, chromosomes, or Guilford, 1995), 6.

R. D. Hare, Without Conscience: the Disturbing World of the Psychopaths (New York:

2 I. Sahlin, "Psykopatibegreppets Renässans," in Ord och Bild, 4:5 (2002), 62.

(c) 2010 Roland Paulsen

http://www.kritike.org/journal/issue 8/paulsen december2010.pdf ISSN 1908-7330 
in minimal brain damages or the like), was gaining in popularity during the second half of the $19^{\text {th }}$ century and was widely prevalent during the $1920 \mathrm{~s}$. The concept was also used by some scientists after World War II but this research was then ill reputed (outside certain academic institutions) while more sociological concepts such as the Frommian authoritarian character gained in public confidence. In the criminal journalism during the 1970s, for instance, an emphasis on social reforms to counteract criminality reflects this general attitude as Pollack has pointed out. ${ }^{3}$

During the last decade however, the concept of psychopathy has experienced what Sahlin describes as a renaissance-both in scientific and popular contexts. Again, the focus is on individual biology. Pollack asserts that the journalism of this decade is marked by "provincial populism." Violence as such is the news and its reasons are increasingly neglected-"background analysis are uncommon in the media texts [...] Explanations of crime are in the media based on evil, criminal gangs, ethnicity and racism."4 In this climate of relative lack of social criticism, the revival of the psychopath seems understandable and not very surprising. When it enters popular culture, however, observing this development as a fact does not serve any critical purpose, as Nelkin and Lindee argue. ${ }^{5}$ We need to analyze in detail the ideological content of the concept of psychopathy and what it involves when popularized as today. What causes for aggressiveness are pointed out? How does the notion of psychopathy teach us to deal with aggressive people? These questions structure the first part of this article and will serve as a foundation of critical analysis of the notion of responsibility, the role of power, and overt and hidden values in the psychiatric discourse.

\section{Sources and Implentation}

Critical research on the concept of psychopathy has so far focused on scientific literature, which surely gives a good picture of the discourse. ${ }^{6}$ As Lukács puts it, "you do not have to read a philosopher to get your world view affected by him [...] There is secondary literature, there are articles, reviews and journals, radio lectures and much else." Still, we consider these concrete popularizations to be of great interest. In popular media we might for example find scientific theses formulated more bluntly or perhaps even in a way that distorts their meaning. To understand the ideological impact of a scientific theory we therefore have to analyze some of its concrete popularizations. Data for our analysis has been obtained via database searches (Westlaw

\footnotetext{
${ }^{3}$ E. Pollack, En Studie i Medier och Brott (Stockholm: JMK, 2001).

${ }^{4}$ Ibid., 336

5 D. Nelkin and M. S. Lindee, The DNA Mystique (New York: W. H. Freeman and Company, 1995).

6 J. G. Murphy, "Moral Death: A Kantian Essay on Psychopathy" in Ethics, 82:4 (1972), 284-298; Sahlin, op cit.; R. J. Smith, "The Psychopath as a Moral Agent" in Philosophy and Phenomenological Research, 45:2 (1984), 177-193.

${ }^{7}$ G. Lukács, Förnuftets Banemän (Lund: Arkiv förlag, 1985), 8.
} 
International, Mediearkivet and Presstext) for all available published articles pertaining to the diagnosis of psychopathy, beginning in January 2003, up to and including January 2006. The study includes texts from media scientific reporting in newspaper written for a wide general readership in two countries: Sweden and the UK. The reason we have chosen the material from two countries is that the articles that treat psychopathy (the diagnosis) specifically are too few in each country during the selected period to provide empirical saturation. From these combined sources about 50 texts have been collected, and from these a final 20 have been chosen for detailed analysis based on the frequency of the keywords "psychopathy" and "psychopath." Most of the analyzed articles are feature articles that distinctly discuss the phenomenon of psychopathy; we have only found one article that belongs to the genre of criminal journalism.

The intention of this paper is to attempt a reconstruction of the discursive framework of these articles. Although this is a critical discourse analysis, the notion of "discourse" that we refer to, has more in common with the Foucauldian one than with the notion(s) present within what is usually referred to as CDA. ${ }^{8}$ Since the phenomenon of psychopathy is primarily discussed within the field of science, the focus here will be on the intertextuality between analyzed articles and texts from more scientific genres 9 such as psychology, sociology and philosophy. Intertextual analysis, according to Fairclough, draws attention to how "texts selectively draw upon orders of discourse - the particular configurations of conventionalized practices (genres, discourses, narratives, etc.). ${ }^{10}$ This occupation with the provenance of the order of discourse ${ }^{11}$ which suits our interests stated in the introduction, touch upon the more archaeological analysis conducted by Foucault with the purpose to "set statements in their discursive frameworks." 12 "Intertextual analysis crucially mediates the connection between language and social context," as Fairclough puts it, and especially when exposing what is often the best proof of power relations embedded in a text, namely the "absences." 13 As we search for the origins of the media order of discourse in the scientific genres already mentioned, we will also put forward some alternative approaches to psychopathy in each genre.

8 N. Fairclough, Media Discourse (London: Edward Arnold, 1995). 56; S. Mills, Discourse (London: Routledge, 1997), 17; R. Wodak ed., Methods of Critical Discourse Analysis (London: Sage, 2002), 9.

${ }^{9}$ Genre should here be comprehended in the Bakhtinian sense, i.e., constituted by its addressivity - to whom the utterances constituting the genre are addressed. M. M. Bakhtin, "Speech Genres and Other Late Essays," in N. Coupland, and A. Jaworski eds., The Discourse Reader (Surrey: Routledge, 1999), 132.

10 N. Fairclough, (1999) "Discourse and Text: Linguistic and Intertextual Analysis within Discourse Analysis," Ibid., 184.

${ }^{11}$ Ibid., 191.

12 Mills, op cit., 49.

${ }^{13}$ Fairclough, "Discourse and Text," 185. 
This investigation of the "intertextual potential"14 of the media order of discourse will be quite extensive. According to Fairclough textual analysis often misses what is excluded in the text. A possible explanation could be the vast (often technical) knowledge required to perform a genuine intertextual analysis. Such analysis requires much work and is, unlike most of the critical discourse analyses, deductive rather than inductive in character. Here, the use of Fromm's sado-masochistic character as a contrast to the theories of psychopathy will serve as a tool in our analysis. However, we are not intending to present the accurate theory of psychopathy, only to prove that relevant information in the subject is omitted and that these absences may indicate ideological media representation of an important matter to the public.

\section{Lay Preacher Aetiology}

A problem, both in clinical and everyday situations, is that psychopathy is a double, almost contradictory diagnosis. The psychopath is a monster, but his terrible characteristics are hidden behind a "mask of sanity" as Cleckey has described it. ${ }^{15} \mathrm{He}$ is partly described as extremely empathic and manipulative_- "A good psychopath can play a concerto on anyone's heartstrings"16 - partly as a socially disabled "child" (as the Harvard psychologist Kegan has described it) unable to learn socially accepted codes and values. The diagnosing procedure may easily end up in what Popper terms a close circle argument. ${ }^{17}$ If we suspect someone for being a psychopath, both crimes and deeds can be used as proofs of psychopathy. We may never falsify the diagnosis since it is impossible to know when the presumed psychopath is being manipulative and when he reveals his "true self."

Psychopathy can also be difficult to distinguish from other diagnoses. According to Hare, even clinicians are confused as for the difference between psychopathy, sociopathy and antisocial personality disorder which are the most adopted diagnoses of criminals in psychiatry. ${ }^{18}$ In her widely acknowledged The Sociopath Next Door, Stout uses the terms sociopathy and psychopathy interchangeably as if they represented the same phenomenon. Hare on the other hand, asserts with the Bible of psychiatry (DSM IV) behind him, that psychopathy is more deeply rooted than sociopathy and antisocial personality disorder since it is defined not only by a cluster of socially deviant behaviors, but also by personality traits. This means that we should not be amazed if journalists writing about psychopathy adopt biological models for human

14 Ibid., 205. 1978), 164

15 H. Werlinder, Psychopathy: A History of the Concept (Uppsala: Almqvist \& Wiksell,

16 R. D. Hare, "The Revised Psychopathy Checklist: Descriptive Statistics, Reliability, and Factor Structure," in Psychological Assessment, Vol. 2 (1990), 339.

${ }^{17}$ Cf. Sahlin op cit., 68.

${ }^{18}$ Hare, Without Conscience, 25 
behavior. The naturalizing of human phenomena is an ancient phenomenon that is now advancing - an advance observed by many scholars. ${ }^{19}$

Still, nurture is considered to be of some importance for the outbreak of psychopathy-nature and nurture are in "interaction" with each other, it is said. In the following paragraph, we will discuss how this interaction is explained. Furthermore, we will look into how media, despite the stress on biology, explain why psychopaths often are successful in climbing the hierarchies of society. Eventually we will analyze-in detail-how the psychopath's genetic predispositions are supposed to differ from the general set of genes.

\section{The "interplay"}

"Evidence that psychopaths are born, not made";20 "Beware the psycho who's born mean";21 "Psychopaths 'inherit anti-social traits"22 — these headlines indicate quite clearly what dominating explanation of psychopathy is circulating in the media. Psychopathy has for a long time been considered a natural phenomenon that has nothing to do with environmental forces. Cleckley, for instance, commented that "during all my years of experience with hundreds of psychopaths [...] no type of parent or parental influence, overt or subtle, has been regularly demonstrable." 23 Thanks to the development of psychodynamic and behaviorist theories (and probably the critique from the anti-psychiatry movement) biological theories about psychopathy have, however, been somewhat modified. Today the standard explanation is that psychopathy originates in interplay between biological factors and environmental forces. ${ }^{24}$

This more balanced view is also adopted by the newspaper journalists to some extent. We see it in reservations about the evident importance of the environment, often expressed in one sentence while the main part of the article treats why biological factors are so important to the study of psychopathy. In the Economist one can read that biologists have come to understand "what was blindingly obvious to most laymen - which is that rather than being shaped by nature or nurture, most behavioral traits are an interaction between the two." 25 In the next sentence we read: "Nevertheless, one or the other can still be the

19 P. Brodwin, "Genetics, Identity and the Anthropology of Essentialism," in Anthropological Ouarterly, 75:2 (2002), 323-330; Nelkin \& Lindee, op cit.; J. Rifkin, The Biotech Century (London: Victor Gollancz 1998); J. Radden, "Commentary on 'Psychopathy, Other-Regarding Moral Beliefs, and Responsibility" in Pbilosophy, Psychiatry \& Psychology, 3:4 (1996), 287-289; P. R. Wolpe, "If I Am Only My Genes, What Am I? Genetic Essentialism and a Jewish Response" in Kennedy Institute of Ethics Journal, 7:3 (1997), 213-230.

${ }^{20}$ Economist, 050528.

21 Birmingham Post, 040911.

22 Daily Telegraph, 050525. Sons, 1970), 97

${ }_{23}$ Quoted in R. D Hare, Psychopathy: Theory and Research (New York: John Wiley \&

\footnotetext{
${ }^{24}$ Hare, Without Conscience, 166
}

${ }^{25}$ Economist, 050528. 
dominant factor."26 Another example is given in where the psychiatrist JanOtto Ottoson, without being questioned about it, ticks off the importance of environmental factors in the following way:

Of course, childhood plays an important role in these people's lives, as in everybody else's. But biology is also very important. The psychopaths often suffers from a function disorder in the brain: Reduced blood-flow in the frontal and parietal lobes, reduced serotonin-level and increased dopamine-level and so forth. ${ }^{27}$

What in the environment that plays the important role is impossible to tell from the articles that we have analyzed. The most concrete environmental factor is presented in another interview with a psychiatrist: "For instance to watch many and extreme films containing violence. To a fragile personality these films might hurry up the course of event."28

As will be seen from the examples, the greater part of the explanations is devoted to the abnormal biology of the psychopath and, but not to the same extent, how much percent of the disease can be explained by biology $(80 \%$ according to the Economist and the Birmingham Post). ${ }^{29}$ These percentages are all based upon twin-studies where identical twins are compared with fraternal twins with the aim of investigating how important identical genes are for the development of certain diseases. In these investigations the only part of nurture that can be measured and explained is, however, behavioral differences according to the individual (not the common) environment-the existence of the behavior as such, why anyone can behave as psychopath in our society, is not discussed in the analyzed articles. ${ }^{30}$ Psychopathy simply appears as a "fact of life"; an unavoidable problem, still necessary to be dealt with by means of psychiatry.

This reduction of nurture is of course an achievement of the psychiatric discourse and when reading what Hare, among others, means when he speaks of interaction between nature and nurture, this becomes still more obvious. Hare rejects categorically the psychodynamic "cycle of abuse" theories saying that those who have been victims of violence in their childhood easily turn into perpetrators themselves. Hare even rejects the more farreaching theory of detachment disorders that also pay attention to subtle forms of detachment in infancy that might lead to deviant behavior later in life. Such disorders might lead to anti-social behavior, even though some people seem to be invulnerable, 31 but not to psychopathy. "While some assert that psychopathy is the result of attachment difficulties in infancy, I turn the

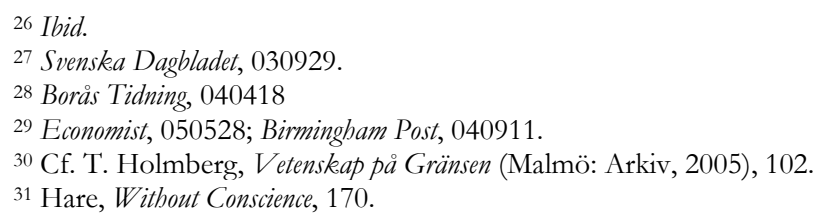


argument around: in some children the very failure to bond is a symptom of psychopathy." 32 The child is born with psychopathy, Hare asserts, and this is important to acknowledge, he proceeds, since many parents to psychopaths unjustly suffer from guilty conscience about something they are completely innocent of 33 - "their psychological guilt trip to find out where they went wrong is not very likely to be fruitful." 34 Still poor parenting or adverse childhood experiences cannot be completely disregarded in the study of psychopathy. The environmental factors play, according to Hare, an important role in shaping what nature has provided. "No amount of social conditioning will by itself generate a capacity for caring about others or a powerful sense of right and wrong" Hare declares. ${ }^{35}$ These capacities are learnt by "normal" persons but to learn these affective properties is exactly what the psychopath is incapable of.

To sum up, we see in the psychiatric discourse that individual childhood experiences might, at the utmost, influence the shape and behavioral aspects of psychopathy, while the remaining part of what we refer to as environmental forces on the whole is ignored. In the press, this lack of sociological analysis is even more striking. Behind the phrases about "interaction" and "interplay," we ultimately find the old biological model of Cleckley leaving the importance of society unrecognized. A good summary of where the dominating research in the aetiology of psychopathy stands today, is given in Helsingborgs Dagblad: "Neither himself [the Swedish psychiatrist Sten Levander] nor Hare pretends that the childhood is unimportant, but psychopaths would go astray even in an utopian society." 36 The role of society is not discussed anymore than that. Apparently, nurture is considered in the quotation, but whatever could point towards societal encouragement of psychopathy is not on an explicit level discussed in the least-neither by the interviewed psychiatrists, nor by the writing journalists. Yet, we touch upon the subject when non-criminal psychopaths who are socially "successful," are being treated.

\section{Successful Psychopaths}

The closest we get to the importance of social structures to the development of psychopathy, is when the psychopaths' often-successful careers are being discussed. Psychopaths are not necessarily criminals, one points out repeatedly, but examples of the legal kind of psychopaths and what they concretely might be up to are not given. "There are many similar core personality characteristics in criminal psychopaths that are found in other walks

32 Ibid., 173.

33 As Kärfve points out, these guilt relieving explanations of parental behavior and dysfunctional families are also prevalent when the child suffers from the ADHD/DAMP-label. E. Kärfve, Hjärnspöken: Damp och Hotet mot Folkbälsan (Stockholm: Symposion, 2000), 156.

${ }^{34}$ Hare, Without Conscience, 173.

35 Ibid., 174.

${ }^{36}$ Helsingborgs Dagblad, 030918. 
of life," Hare says in the Evening Standard. ${ }^{37}$ In the Independent he goes more into detail: "Psyhopaths'] ability to manipulate others without remorse, coupled with a veneer of charm, can also make them extremely successful in many walks of life, including business." 38 In an article in Expressen, where, oddly enough, Hare is not mentioned (though still quite present), we can also read: "studies indicate that one of 20 employers and one of 40 employees are psychopaths." 39 In Dagens Nyheter the share of psychopathic bosses is deemed $10-20 \%{ }^{40}$

Does not this suggest that psychopathy is encouraged and stimulated by Western capitalism? Even if so, it remains out of the question in the analyzed articles. Instead we learn that also the social selection of these people is a natural phenomenon: "[S]ome of us are born with psycho genes. The fact that natural selection has allowed them to persist would suggest that, in milder forms at least, psychopathy might be useful." 41 The problem seems to be that society is not controlling the "laws of Nature" sufficiently. The survival of the fittest is the principle of nature, not, as Spencer once suggested, a mark of civilization. The civilization stands on the contrary alone as the single authority able to counteract the principle of natural selection. This is ironically proved by the psychopaths' success. If the number of psychopaths were allowed to grow unrestrained, there would be no relative advantage of being a psychopath:

Though the genes in question have yet to be identified, this result suggests they are too abundant to be there by chance--in other words they are being kept in the population by natural selection because psychopathic behavior confers a selective advantage. If it does, such an advantage probably pertains only when psychopaths are in the minority (a state of affairs known to biologists as a balanced polymorphism)..$^{42}$

If we do not protect ourselves against nature, nature may accordingly interfere with social processes. In nature there is, however, an immanent logic guaranteeing that psychopathy does not become too prevailing. The same logic also seems to have been adopted by the heralds of civilization. Hare does not want to eliminate psychopathy as such: "The idea is not to give this people the boot. Some organizations would value some of the traits, such as being remorseless." 43 The purpose of the psychiatric science is to control the disease and only as long as it is remains uncontrolled, psychopathy constitutes a problem.

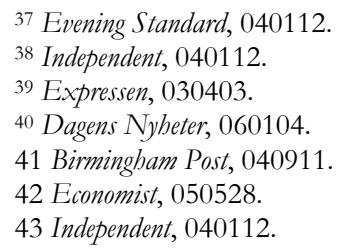




\section{The Uncivilized Man}

Conflict between civilization and the untamed nature runs all through the analysed reporting on psychopathy. In this section I will discuss more in detail how the psychopath biologically differ from what is normal. Nelkin and Lindee maintain that before science replaced religion, the equivalence of the psychopath who also hided his evil behind good appearances, was not a product of "bad seed" but of a bad soul. ${ }^{44}$ When this abstract unity, the soul, disappeared from the scientific theories, the equally very abstract DNA was eventually introduced as an unavoidable factor for both science and philosophy. In this way, the fatalism characterising some of the religious theories about the human being was being maintained and quite liberally applied in many modern theories. The psychopath and the "dark soul" are, however, different from each other in many ways. Especially since the dark soul was considered the devil's own invention put into the image of God, while psychopathy on the other hand is thought to be representing something fundamentally human - an aspect of humanity that society fortunately has been able to keep in check.

Cesare Lombroso was an Italian physician who lived during the $19^{\text {th }}$ century. He is generally considered the founder of modern criminology. A central point of departure for his theories was the notion of the born criminal (delinquente nato). Lombroso was heavily influenced by the evolutionist currents of his time and thought that some people were inferior beings whose higher nervous centres-where the moral sense was supposed to be situated-were not as developed as in the civilized man. These higher nervous centres were considered to have developed in man at a very late date and sometimes the evolution could take a step back and create individuals who were hopelessly destined to become criminal. These individuals, Lombroso asserted, shared their biology with primitive people- they were simply unsocializable savages who happened to be born among civilized people. "Lombroso couldignorant of 'savages' as he was-find many parallels between them and the extreme criminal: various ways of killing human beings, promiscuity, pederasty, inclination to tattoo oneself, etc." 45

The similarity between the born criminal and the psychopath is striking - both concepts represent individuals who for biological reasons are unable to socialize into society and internalize its alleged norms. They are strictly speaking not mean people_-just primitive men whose buman nature cannot be restrained by society. Just as Lombroso would link the born criminal to the childhood of civilized people, modern psychiatrists view psychopathy as a form of developmental delay. Harvard psychologist Robert Kegan, for instance, has argued that behind Cleckley's "mask of insanity" lies not insanity but a young child of nine or ten. "The basis for this theory is twofold," Hare writes:

${ }^{44}$ Nelkin \& Lindee, op cit., 41.

45 Werlinder, op cit., 72. 
"similarities between the EEGs (recorded brain waves) of adult psychopaths and those of normal adolescents; and similarities between some of the psychopath's characteristics-including egocentricity, impulsivity, selfishness, and unwillingness to delay gratification-and those of children." 46 In an interactionist model drawn up by the sociologist Harrison G. Gough, the psychopath is similarly defined as deficient in the normal role-playing abilities. ${ }^{47}$ The psychopath is simply a person who is unable to socialize or who at least has great problems in doing so. "According to Sten Levander there is only one assured cure for those who have developed full psychopathy, and it is time. The extreme traits tend to fade away at the age of 25 and after 40 it goes faster and faster. They eventually learn the social rules, even if it's a slow business. A psychopath at the age of 75 is very rare"-ends an article in Dagens Nyheter which serves as a good example of the view of the psychopath as an unadjusted child. 48 The reason for this difficulty to socialize is yet unknown, but the theories are, as already stated, all based on the model in which genetic heritage amounts to "the brain of the psychopath treating emotional information differently than the normal population." 49

The interesting part of this socialization theory is that it does not only make assumptions about the nature of the psychopath but also about human nature as such. Quite contrary to the Rousseauan humanism, the basic assumption seems to be that there is a self-destructive element in humanity that must be kept in check by people collectively controlling each other through what we call society. This assumption is to be found in some Freudian and Nietzschean currents, in the founder of sadism, Marquis de Sade and originally in the English philosopher Thomas Hobbes. According to Hobbes, the human being, like all other animals, primarily follows the instinct of self-preservation. In order not to end in devastating civil war, mankind has decided to restrain this instinct by delegating all individual power to the state (represented by an absolute, irremovable sovereign, Hobbes argued).

The most important consequence of the instinct of self-preservation is, according to Hobbes, in each man an endless striving for power. "A general inclination of all mankind" he writes, "[is] a perpetuall and restlesse desire of Power after power, that ceaseth onely in Death. And the cause of this, is not always that a man hopes for a more intensive delight, than he has already attained to; or that he cannot be content with a moderate power: but because he cannot assure the power and means to live well, which he hath present, without the acquisition of more." 50 As Murphy comments "the men he [Hobbes] imagines in a natural state (motivated only by the egoistic desire for personal satisfaction and the preservation of their own lives) are all

${ }^{46}$ Hare, Without Conscience, 168.

${ }^{47}$ H. G. Gough, "A Sociological Theory of Psychopathy," in The American Journal of Sociology, 53:5 (1948), 362

48 Dagens Nyheter, 060104.

49 Svenska Dagbladet, 040331.

${ }^{50}$ T. Hobbes, Leviathan (St. Ives: Penguin Classics, 1968), 161. 
psychopaths" 51 and as long as obedience, or to use a more modern term, "social norms" have not been established, man remains a psychopath.

These sorts of evolutionist theories are difficult to refute within the frame of positivist science from which they originate. "From Hobbes to Hitler" Fromm writes, "who explains the wish for domination as the logical result of the biologically conditioned struggle for survival of the fittest, the lust for power has been explained as a part of human nature which does not warrant any explanation beyond the obvious." 52 Once nature or "the cruel Queen of all wisdom" as Hitler called it, is accepted as the fundament of human behaviour, it is easy to even in the most flagrant evidence that society is corrupting man (and not the opposite), assign it to human nature. ${ }^{53}$ The most astonishing results presented by Stanley Milgram in his study of obedience, have for instance been read as empirical evidence of the obedient aspect of human nature, not of modern living individuals brought up in Western capitalism. ${ }^{54}$ The sociological (and historical) imagination of which the American sociologist C. Wright Mills wrote is here completely absent. And for good reasons - "the one who has secured the right to define the notion of Human, holds trumps" as the Swedish sociologist Joakim Israel asserts. ${ }^{55}$ Still, neglecting to analyse the social circumstances under which individuals live their lives, implies in itself not only an assumption about human nature, but also a sociological assumption, namely that nothing can make man behave differently from how nature has already programmed him. What Hobbes and the modern neurologists are saying when asserting that the psychopath essentially is a nonsocialized man, is that society (in form of collective obedience, social norms, democracy etc.) does not deprave man additionally to how nature has already created man, but on the contrary, alone, guarantees human peace. In the next section where I will analyse the hitherto devised strategies for treating psychopaths, this sociological assumption will be discussed more in detail.

\section{The Treatment}

Psychopathy is a disease that is generally (i.e. amongst the leading expertise) considered "untreatable." 56 To quote some journals: "it cannot be treated" 57 or, at least, "there is no proof that psychopathy can be treated";58 or to quote Hare: "there is little convincing scientific evidence that psychopaths $4(1972), 293$

51 J. G. Murphy, "Moral Death: A Kantian Essay on Psychopathy" in Ethics, 82:

${ }^{52}$ E. Fromm, Escape from Freedom (New York: Owl Books, 1941), 146

53 Ibid., 226.

54 Cf. M. A Hogg and G. M Vaughan, Social Psychology (Gosport: Pearson, 2005), 252; M. Stout, The Sociopath Next Door (New York: Broadway Books, 2005), 63.

55 G. von Heijne and J. Israel, Skapelsens Herre eller Genernas Slav? (Stockholm: Ordfront, 1985), 7.

56 North Devon Journal, 051013.

57 Dagens Nyheter, 040507; Svenska Dagbladet, 030919.

${ }^{58}$ Dagens Nyheter, 040310. 
respond favorably to treatment and intervention." 59 The conception of the incorrigibleness of psychopathy is obvious in every newspaper discussing the problem. This, considering the logic of the psychiatric discourse, is not very surprising-since human nature is hardly influenced by social forces at all, the effectiveness of therapy remains rather minimal. Psychopathy is an "inborn and incurable disease" 60 as it says in one paper, and "some studies suggest that earlier attempts to put psychopaths through therapeutic programmes may actually have made them more dangerous" another one reads. ${ }^{61}$

Still the newspapers hardly breathe any desperation. That a mode of treatment has yet not been found does not mean that it never will be. Today, the media lay stress on spotting the behavior as soon as possible which, since it is innate, means quite early. How to treat the problem once disclosed is not obvious. "Psychopathic offenders create stark choice" Hare says to the Observer, "do we simply keep them in prison until they are old enough to pose little risk? Or do we find ways to teach them more pro-social ways... to satisfy their needs and wants?" 62

In this part, these questions will be carefully discussed from what the articles say. To begin with, we will however discuss where the responsibility is considered to be-in the psychopaths, in their parents, in the mental health services or elsewhere? The function of psychiatric control and power will subsequently be discussed in detail. As we shall see, power is cherished both in the psychiatric discourse and by psychopaths. This leads us to the question of whether the psychopath is as incapable of adopting dominant values as it is generally assumed. In an attempt to answer this question, we will make a distinction between a-values and b-values - values that are officially preached and embedded values that structure social behavior.

\section{Who to Blame}

In relation to the completion of the draft map of the human genome (June, 2000), publicly known as the Human Genome Project, many commentators feared a new segregation based on genotype could unfold out of the newly gained genetic information. ${ }^{63}$ This apprehension was, and still is, quite misdirected. Exactly which genes that cause a human behavior whichever remains utterly unknown and there are good reasons to doubt that such knowledge will ever occur. ${ }^{64}$ Yet, a cultural segregation based on the belief that man is predetermined by an individually inherited nature, may occur irrespective of scientific progress. What we need to ask ourselves is if this really

59 Observer, 051120

${ }^{60}$ Helsingborgs Dagblad, 030918.

${ }^{61}$ Observer, 051120.

${ }^{62}$ Ibid.

63 P. McCann-Mortimer, M. Augoustinos, and A. LeCouteur A., "Race' and the Human Genome Project: Constructions of Scientific Legitimacy," in Discourse \& Society, 15:4 (2004), 409; Nelkin \& Lindee, op cit., 165; Rifkin, op cit., 160.

${ }^{64}$ Nelkin \& Lindee, op cit., 199; Rifkin, op cit., 157. 
would constitute a new sort of segregation? Even in the merithocratic system of assessment there is an idea of a strong, gifted class of individuals, and a "genetic underclass." The only thing differentiating our cult of heredity from what the future possibly holds in store is that today the wheat is sifted from the chaff primarily by means of education and labor, whereas, in the future, a feudal system based on family may be revived if the gene cult is driven to an extreme.

"What if other genetic research should provide cast-iron evidence of genetic links to such traits as alcoholism, aggression, psychopathy or other antisocial behavior?" a chronicler in the Sunday Times asks. ${ }^{65}$ "Who will have access to the data? How will it be used? Will anyone profit from the findings?" In this kind of criticism of the biologist paradigm, the gene as a holy icon has already been adopted. It is not a question of whether the heredity theory is true or not- - only of how the enormous information might be used. In Sweden, 1,835 psychopaths—mostly women—were sterilized during 1941- 1953, according to Sahlin. ${ }^{66}$ What violation and manipulation of human nature is not to be expected when the renaissance of the concept of psychopathy coincides with what Rifkin has termed the "biotech century"?

Sahlin believes the revival of the concept of psychopathy is connected with a trend to individualize social problems and search for solutions in inhumane methods of manipulation. ${ }^{67}$ From the analyzed material we have found that in the contemporary discourse of psychiatry, no individualization of psychopathy or genetic manipulation to prevent the spreading of the disease is actually suggested. Psychiatry is no longer as isolated as before; it is defending itself against external discourses - to a certain degree, one might add. For instance, the criticism that the psychopathy label may become a "self-fulfilling prophecy" when negative expectations are subtly conveyed to the individual (a criticism delivered by Sahlin ${ }^{68}$ among others) is open-heartedly discussed by Hare who even admits that the psychopathy diagnosis might harm and that it should not be used if there is even a slight hesitation about its convenience. ${ }^{69}$ In the same way one avoids, both in specialist literature and in newspapers, to individualize the problem, at least on an explicit level. On the contrary, the attack is upon the individualization found in psychoanalysis where, one asserts, parents have been throughout accused-" "the parents of a young psychopath who have turned their lives upside down, in spite of their frantic attempts to understand and nurture him or her, will find it doubly difficult to bear when society unfairly blames them for the problem." 70 Since the influence of nurture is reduced to what the abuse cycle theories amount to, all who try to focus on social causes behind psychopathy can be charged with individualizing the problem to the parents. The biologists themselves do not blame the parents in

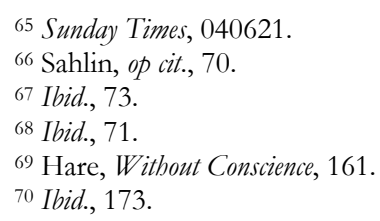


any way - not even for having children in the first place. Since we cannot know how and which genes are being passed on, there is (so far) no public discussion of the responsibility of the parents. Parents therefore find the biological explanations of diseases including psychopathy, as a relief from guilt. ${ }^{71}$

"One per cent of the population is psychopathic" 72 Hare says to the press and nobody can be accused of this. Not even the born psychopath-he cannot help he is born as he is. Nature is the reason-no one can be held responsible for brain dysfunctions, as Kärfve points out. ${ }^{73}$ This is why it might be appropriate to say that the soul has been "biologized." 74 Instead of viewing children as possessed by the devil, children are nowadays possessed by their "evil" genes, and although the stigmatization process will certainly inflict harm the children are not to be morally blamed.

What consequences might follow out of this complete naturalization of the problem? In brief, we are not dealing with an individualization of aggressiveness, but with an essentialist and even fatalist belief that mother earth governs human behavior. It is not unreasonable to imagine that this fatalism might lead us, and especially our children, to the same state of uncertainty and brooding on who we are as in the Calvinist movement of the $17^{\text {th }}$ century. ${ }^{75}$ How can we be sure that we are the talented ones? The intelligent ones? The ones meant to succeed? Or the ones with ADHD? How can we be sure of our sexuality? How can we be sure of not being psychopaths? A perpetual selfexamination is apt to develop out of this fatalism and is probably quite scattered already-empirical research needs to be done here. As we shall see, society willingly provides the tools and categories for this kind of "soulsearching."

\section{Power and Control}

Taking the long view, one might say the striving to dominate the human body constitutes the final point of what Francis Bacon regarded as the great project of civilization: “to 'squeeze', 'mould' and 'shape' nature, in order to 'enlarge the bounds of human empire to the effecting of all things possible." 76 As Adorno and Horkheimer argues in The Dialectic of Enlightenment, this will to dominate nature has become an axiom for the Western civilization. It has become so fundamental, the original motive for it (to increase human happiness) has been forgotten while the means (domination over nature and

${ }^{71}$ Cf. Nelkin \& Lindee, op cit., 142; Kärfve, op cit., 79.

72 Evening Standard, 040112; Birmingham Post, 040911.

${ }^{73} \mathrm{Kärfve}$, op cit., 212. By giving in to biological essentialism, gay rights activists have accordingly won much of the increasing legitimacy of homosexuality. This, however, has not been realized without criticism from queer-feminism. Cf. Nelkin \& Lindee, op cit., 121; Wolpe, op cit., 214.

74 Wolpe, op cit., 217

75 Cf. M. Weber, Den Protestantiska Etiken och Kapitalismens Anda (Lund: Argos, 1978),

52.

${ }^{76}$ In Rifkin, op cit., 170. 


\section{MEDIATED PSYCHOPATHY}

other human beings) lingers on. ${ }^{77}$ "The means is fetishized: it absorbs pleasure," they observe. "Just as the goals with which the old system of rule had veiled itself, are rendered illusory by enlightenment in theory, the possibility of abundance removes their justification in practice. Domination survives as an end in itself $[. .$.$] "78 The will to emancipate man from his nature,$ or, perhaps more correctly, to make his nature harmonize better with the demands from society, is an integral part of what Marcuse succinctly describes as the "domination of man by man through the domination of nature." 79

Even if some of the scientific projects indicate that this form of manipulation of the human being through nature (i.e. through the body) is something highly desired, the study of how psychopathy is treated in the dominant psychiatric discourse teaches us that these rather advanced forms of manipulation-especially gene manipulation-are not considered as realistic alternatives. What we, on the other hand, recognize is an attitude towards the psychopath as if he was a natural phenomenon, an unchangeable thing. What we recognize is a tendency to equal domination of man with domination of nature.

Modern domination of nature is not as conspicuous as domination of man. The biological aetiology should perhaps make gene manipulation more material to the discussion than it is. But there are no tools for this kind of manipulation and even if psychopathy is considered to originate in the genes, no one knows or even claims to know which genes we are dealing with. Even if some prophesying chroniclers fear that the question of gene manipulation may become urgent in the future, ${ }^{80}$ it is not even mentioned in the scientific reporting. The fear of being associated with eugenics is furthermore too great to speak in favor of forced sterilizations or the now employed but still quite controversial electro-shock therapy. The closest we get to any suggestion of domination over man through his body in the dominant discourse is via medication; a relatively imperceptible modification of the brain, allegedly momentary and therefore legitimate to advocate in public.

As for the rest, the modern project to dominate nature is primarily used as a pretext for exercising power over both potential and diagnosed psychopaths. The first step is to reduce the psychopath to a natural phenomenon. Since psychopathy is described as a biological complaint, the one-dimensional positivist reduction of the psychopath to an unchangeable object without any potential to transcend his own limits, gains increased credibility. Just as parents are told they should not take so much responsibility for their children since the children's genes ultimately determine their behavior and future achievements, society cannot answer for helping psychopaths to get rid of their psychopathy.

77 T. W. Adorno and Horkheimer, Dialectic of Enlightenment (Stanford: Standford University Press, 2002), 72.

${ }_{78}$ Ibid., 82

${ }^{79}$ H. Marcuse, One-Dimensional Man (Boston: Beacon Press, 1991), 158.

80 Sunday Times, 040621. 
"Predisposition helps to construct a philosophy of limits" Nelkin and Lindee assert. ${ }^{81}$ Central to this philosophy is that man-every man-remains limited by nature and that every attempt to make him transcend his inherited limits is doomed to fail. In a speech to a group of police chiefs in 1981, President Reagan blamed the belief that changing the environment could change man into the better to be responsible for crime. What prevented justice was, according to Reagan, "a belief that there was nothing permanent or absolute about any man's nature." 82 This belief is completely in contrast to the philosophy of limits. ${ }^{83}$ Instead of caring about changing society, the philosophy of limits says we should protect society against the harmful aspects of human nature. Once the philosophy of limits is established, social domination over man thus appears as domination over nature - as an absolute necessity.

The focus both in specialist literature and popular media concerning the handling of psychopathy is not upon how to eradicate the disease but upon how to spot it as early as possible. The extensive instructions (however vague they may be) given to the newspaper readers on how to recognize a psychopath especially at the place of work but also in the private sphere, therefore serves a practical purpose. Since psychopaths will always exist, people must learn to be on their guard against each other, "for if we can't spot them, we are doomed to be their victims both as individuals and as a society," Hare explains. ${ }^{84}$ And we better spot them as early as possible. If you should find a psychopath at your place of work, "the only solution if you want to retain your self-confidence and develop as a human being, is to leave," the management expert Lars-Olof Tunbrå says to Expressen. ${ }^{85}$

To spot psychopathic children is not only a task of the authorities; "we must all dare to interfere if we see a child loafing about on his own, torturing animals, beating his friends, setting fire on things or pilfering. These are early hints of warning." 86 It often starts with the steeling of property: "it can begin with pilfering at the age of six and then it continues with the pinching of cellphones, robbery and assault, and if the worst comes to the worst it can end with crimes such as rape and murder." 87 Despite the bestial acts that psychopaths are associated with, psychopathic children are all victims of their own nature and in need of help. "A child with risk behavior must get help to structure his existence and learn to handle social situations" the psychologist Britt af Klinteberg says to Dagens Nyheter. ${ }^{88}$ "Then they can get on relatively

${ }^{81}$ Nelkin \& Lindee, op cit., 136.

82 Ibid., 132.

83 Cf. Marcuse's definition of the human essence: "those potentialities which emerge as the highest on the basis of the attained level of the productive forces and of knowledge." Negations: Essays in Critical Theory (London: Allen Lane, 1969), 163. It should be added that when Marcuse taught at the University of California, Reagan, who then was the governor of California, campaigned to have Marcuse dismissed.

${ }^{84}$ Hare, Without Conscience, 6.

${ }^{85}$ Expressen, 030403.

86 Svenska Dagbladet, 040331.

87 Borås Tidning, 040418.

${ }^{88}$ Dagens Nyheter, 031015. 
well in life. Today society has difficulty in identifying and helping this group of children. Britt af Klinteberg is of the opinion that the knowledge about hints of warnings and special needs should be disseminated to day nurseries, schools and parents as soon as possible." 89

If the disease is not revealed at this early stage, the next "filter" should be in recruitment to labor market and especially to chief appointments. Besides his standards checklist, Hare has for this very purpose developed "the 107point questionnaire known as a 'B-scan' which stands for business scan." 90 The purpose of this scan is, according to the same article, to enable "companies to spot potential managers who are likely to turn violent or defraud the company." "The purpose is to warn the employers" "companies keen to weed out the psychopaths." 22

The risk that this kind of security activity produces psychopaths is treated by Hare in Without Conscience, but not at all in the newspapers. The importance of informing the public about what might be indicating psychopathy is too important for such scruples to be mentioned. Still, the discourse is not plain enough to be charged with advocating a "totalitarianism of hazard prevention which takes the right to prevent the worse and, in an all too familiar manner, creates something even worse," as Ulrich Beck describes postmodern risk prevention. ${ }^{93}$ Primarily since the discourse avoids proposing inhumane methods of treatment. Even if "one might be able to use brain imaging to identify "psychopaths' before they had committed a crime"94 the question remains what to do once the psychopath has been disclosed. Very few articles (three to be exact) treat this problem and we may consequently be unsure of what treatment is actually proposed. It seems the identification (i.e. the stigma) is supposed to put the psychopath into safe custody all by itself, which probably is true. In one article, however, psychiatry proposes what might be called the hard way: the Belgian suspected of murder and pedophilia, Marc Dutroux was judged a "perfect psychopath" and consequently particularly insusceptible to psychological treatment: "to treat a psychopath is impossible and even dangerous and therefore it is best he should never be released, the verdict says." 95 Otherwise, a more cautious attitude is adopted, either by simply declaring that no treatment has so far been able to present any positive results, or by discussing what seems to be the most popular solution of today's psychological problems: cognitive-behavioral therapy combined with psychoactive drugs. ${ }^{96}$

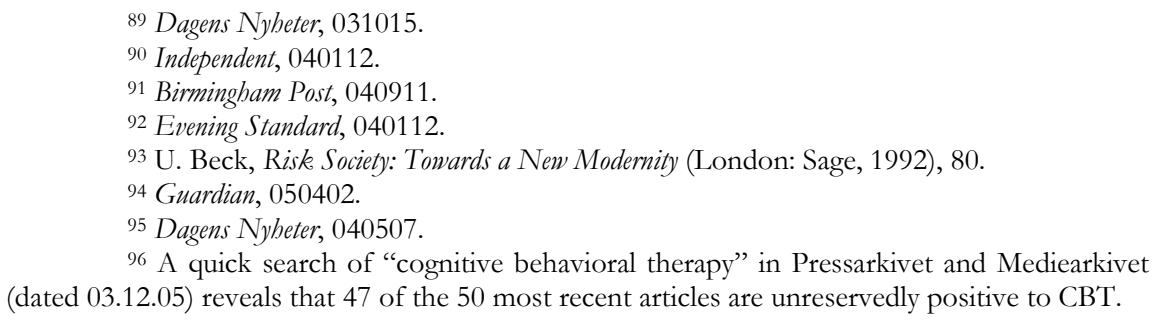


We could only find one article in The Observer where an entirely positive attitude towards the therapeutic part is expressed. ${ }^{97}$ In the article, we find a report from a prison where a quite unique experiment is carried out. "For the first time in the world, a large-scale, sustained attempt is being made to develop and evaluate treatments for men usually regarded as untreatable: recidivist, violent psychopaths." In this article, we have to do with more of a behaviorist discourse than in the other ones. The naturalist view of humanity is, however, the same as in the psychiatric discourse. As Fromm points out, none of the psychiatric discourses takes an interest in the motives and background of the offenders. ${ }^{98}$ Not only biological factors are considered in the explanation of mental illness, but also social causes in the form of learning. Just like Pavlov's dogs, a human being can learn a kind of behavior or thought pattern that sometimes is inconsistent with what is socially acceptable. When changing this behavior, no interest for the character is necessary: the personality of the psychopath is considered immaterial-what matters is only the behavior in itself. Hare's thesis that nurture cannot do anything except shaping the disease ${ }^{99}$ is therefore, in a way, also present in the behaviorist discourse and equally the Cartesian view of man as a mechanical, programmable computer: "cognitive behavioral therapy tries to make an offender aware of the way he processes data, in order to change it."100 This entirely behaviorist form of therapy is in a way similar to the chemical methods of psychiatry and the two kinds of treatments are usually combined.

In another article, positive effects of psycho drugs are presented: "here and there in Sweden serotonin-uptake-inhibitors are given to youths with incipient psychopathy, and this reduces their aggressiveness and impulsivity." 101 The psychopath's distorted picture of the world is, however, intervening too much for psycho drugs to be effective:

At the same time, it's difficult to make them take their medicine. Also psychological help in form of therapy is difficult to offer persons with this kind of disorder.

- Psychotherapy aims at change, and the psychopaths are often happy with their lives. The excitement and stimulation make them feel good. Besides, they have a black and white picture of the world. They think the world consists of oppressors and oppressed, and that if they change their behavior they might become part of the latter group — which, of course, they do not want. ${ }^{102}$

${ }^{97}$ The Observer, 051120

98 E. Fromm, The Anatomy of Human Destructiveness (New York: Holt, Rinehart and Winston, 1973), 44.

${ }^{99}$ Hare, Without Conscience, 203.

100 Observer, 051120.

101 Svenska Dagbladet, 040331.

102 Ibid. 
To sum up, in all articles there is a view of the human being and especially of the psychopath as fundamentally unchangeable because of nature as the determining factor. We might possibly reshape the psychopathic nature to a certain limit but what we really should look after is a deepened control over nature through early spotting of the psychopath, but what to do once the young psychopath has been detected remains unclear. The psychopath label is probably enough of an instrument to put the psychopath into safe custody. As the quotation above indicates, the psychopath is difficult to treat because of his biology. Biology makes him think that the world consists of oppressors and those who are oppressed and that his behavior in this world is rational. ${ }^{103}$ To control psychopathy is therefore a part of the Enlightenment's domination of nature- a part just as evident as the human control over fire. To change society is not an alternative-only more power makes the psychopath manageable. The naturalization of psychopathy indicates something Adorno \& Horkheimer did not articulate, namely that the domination of nature after all is more legitimate than the domination of man. The belief that "advances in neuroscience and genetics will make it increasingly hard to separate 'us' from our biology"104 will therefore pave the way for more use of power in the in the name of Science. The psychopaths become remarkably similar to what Bauman terms the dehumanized objects of bureaucratic operation: "dehumanized objects cannot possibly possess a 'cause', much less a 'just' one; they have no 'interests' to be considered, indeed no claim to subjectivity [...] It is not the objects of bureaucratic action, but its subjects who suffer and deserve compassion and moral praise." 105 In the next part, we will approach the link between this dehumanization and the origin of psychopathy.

\section{B-Values}

In this part we discuss "that other form of madness," as Foucault calls it, "by which men, in an act of sovereign reason, confine their neighbors, and communicate and recognize each other through the merciless language of nonmadness." 106 We have stated that the psychopath is considered non-socialized and by nature incapable of adopting the norms of society which creates problems since the non-socialized person, according to the same discourse, carries an innate badness in the form of endless striving for power. We would now like to enter deeply into which these norms of society actually are.

In a critical article on psychopathy, Smith asks whether the psychopath's values really are as remarkably different from ours as it is causally assumed. ${ }^{107}$ To be able to discuss this question properly, we must, he asserts, make a distinction between a-values: those values certain societies idealize and would like to think are practiced—and b-values: those that widely prevail. In the

\footnotetext{
103 Observer, 051120; cf. Hare, Without Conscience, 203; Stout, op cit., 12. 
psychiatric discourse, a-values are principally taken for granted. To exemplify we might look at how Milgram explains why the participants in his experiment showed symptoms of being heavily under pressure. According to Milgram his subjects got into a conflict situation because they felt caught between obedience to authority and a behavior pattern learned from childhood on: not to harm other people (indeed an a-value). This explanation is criticized by Fromm drawing on what he believes is a b-value: "Have we learned 'not to harm other people? That may be what children are told in Sunday School. In the realistic school of life, however, they learn that they must seek their own advantage even if other people are harmed. It seems that on this score, the conflict is not as sharp as Milgram assumes."108

The purpose here is not to refute the a-values taken for granted by psychiatry, even if such a task would not be very hard to execute. Instead, exclusively based on our analysis in this article, we would like to investigate which b-values the psychiatric discourse itself denotes, and then put these values in relation to the dominating description of psychopathy.

\section{Authoritarianism}

The first and most important value that spring from the psychiatric discourse is: might is right. It is not by changing the fundaments of society that we prevent the spreading of psychopathy but by confirming the collective power over the individual which implies early control, diagnosing, stigmatizing, isolation, medicine and perhaps cognitive-behavioral therapy. This powerglorifying value can, as Horkheimer \& Adorno assert, be traced back to the birth of civilization or, as Fromm formulates it, the changeover from the matriarchal society to the patriarchal society in which man no longer interacts with nature but learns to dominate it and, as a consequence, other men. ${ }^{109}$

The striving for power is, according to Fromm, what characterizes the sado-masochistic character. The sado-masochistic (or authoritarian) character derives pleasure both from submission to higher authorities and from imposing authority on lower strata. This devotion to power is a direct consequence of, and an individual reproduction of the authoritarian society (which includes both capitalist and so-called socialist societies) and is, according to Fromm at the bottom of all from anti-Semitism to necrophilia. ${ }^{110}$ The concept of the sado-masochistic character is a concept just as universalizing as the concept of psychopathy and both concepts claim to explain the same sort of behavior. Nevertheless, the two concepts represent two entirely different paradigms and are therefore dialectically in close relation with each other. While the concept of the authoritarian character derives all human malice from society, the concept of psychopathy views the untamed nature as the problem. A careful

108 Fromm, The Anatomy of Human Destructiveness, 53

109 E. Fromm, The Sane Society (New York: Owl Books, 1990), 47. Society, 152.

110 Cf. Fromm, Escape from Freedom, 148; The Anatomy of Destructiveness, 326; The Sane 
analysis of the diagnosis of psychopathy might however reveal a common denominator in both concepts, namely the striving for power. The b-value that "might is right" which all the diagnosed psychopaths beyond any doubt have observed in their surroundings, not least in both the diagnosing procedure and the following "treatment," virtually knocks out all of the most important avalues that the psychopath offends against.

Even if the psychopath's longing for power is not emphasized in the newspapers, Hare mentions it at several occasions in his book ${ }^{111}$ and it is in no way proved irrelevant in psychiatric literature. In fact, the striving for power is the only common quality one could possibly see in the psychopaths described by Hare and mentioned in the analyzed articles. As we have sought to prove elsewhere, ${ }^{112}$ the other attributes either vanish or are contradicted among the texts contributing to the discourse.

Some of literature's most notorious bad guys bear witness to this striving for power. Instead of paying attention to Camus' relatively harmless character Mersault (described by Murphy as a "perfect psychopath"113) who do not care about neither a- nor b-values and therefore not inclined to offending against any of them, the student of psychopathy should perhaps read Camus' Caligula whose chief character derives his sadistic pleasures, directly from the striving for power: "I live, I kill, I exercise the mad power of the destructor, beside which the power of the creator looks like a cheap imitation. That is happiness."114 "Desire for power after Power that ceaseth onely in Death" as Hobbes writes, ${ }^{115}$ also appears in George Orwell's Nineteen Eighty-Four as leading driving force of a high-profile case of psychopathy: "We are not interested in the good of others; we are interested solely in power," O'Brien says while torturing the principal character Winston. "Not wealth or luxury or long life or happiness: only power, pure power [...] Power is not a means, it is an end [...] The object of power is power [...] 'We are the priests of power' he said. 'God is power' [...]"'116 With the risk of being over-explicit, one might also quote Balzac's clearly psychopathic character Vautrin who, disguised as a priest in Illusions Perdues, proclaims: "I believe in God, but I believe even more in our system, and our system only believes in temporal power [...] I like power for power's own sake!"117 Words we would undoubtedly hear from any eloquent psychopath.

111 Hare, Without Conscience, 5, 38, 100, 104, 216

112 R. Paulsen, Explaining Psychopathy (University of Stockholm: Department of Sociology, 2005)

113 Murphy, op cit., 289

114 A. Camus, Caligula suivi de Le Malentendu (Saint-Amand: Folio, 2003), 148.

115 Hobbes, op cit., 161.

116 G. Orwell, Nineteen Eighty-Four (Suffolk: Penguin, 1972), 211.

${ }^{117}$ Honoré de Balzac, Illusions Perdues (Bourges: Garnier Frères, 1967), 718. 


\section{Essentialism}

If power glorification embraces both the discourse of psychopathy and psychopaths, another common denominator is the deep essentialism that makes all egalitarian efforts appear utterly stupid. Some people are born with an "indifference to punishment." 118 Hence, people are and will always be more false than others. This view of man is very explicit in the media discourse. Sometimes it is even formulated as a direct attack on every egalitarian philosophy that takes for granted that all men are born as equals: "Biologicalinnate-explanations of criminality has not fitted the sociological and political tradition here [in Sweden] where the environment is considered to be the determining factor," Helsingborgs Dagblad writes. ${ }^{119}$ In an earlier article from the same newspaper, we find a quotation of psychiatrist Levander in which he clarifies how egalitarian ideals are in the way of biological explanations: "When one explains this [how psychopathy is genetic], the Swedish social-democracy reacts with: "What? That does not fit our map!"'120 Resistance against onesided biological explanations of human behavior seems however not to be an entirely Swedish phenomenon. In the not so social-democratic US, a psychologist gives a nearly identical explanation to why his theory of inherited shyness has been questioned. "Kagan has been defensive about his findings, suggesting that as a society Americans are reluctant to acknowledge that biological differences exist among children because it violates egalitarian ideologies," Nelkin \& Lindee observes. "Yet," they add, "the response to his work was hardly 'reluctant.' It has been extensively and enthusiastically covered and broadly generalized in the mass media." 121

These quotations clearly points out a threat against the psychiatric discourse, namely the "egalitarian ideologies" which suggests that the value of equality is incompatible with genetic essentialism. This is not very surprising but, on the contrary, logical. If we judge one group of people anti-social by nature and without any potential to change, how can this group of people still be as worthy of the same dignity as the rest of us? According to Murphy, they simply cannot; since psychopaths are "morally dead $[\ldots]$ we have no moral obligations to them and thus our moral response to them is to be on a par with our moral response to animals." 122

Genetic essentialism has rightly been compared to eugenics and its reification, not to say misanthropic reductionism, is beyond any doubt also prevalent among psychopaths themselves. ${ }^{123}$ It was not for nothing that Adorno made the observation that the interviewees who scored high on the fascism scale in the well-known study of the Authoritarian Personality, all assumed

118 Observer, 051120.

119 Helsingborgs Dagblad, 030918.

120 Helsingborgs Dagblad, 011128.

121 Nelkin \& Lindee, op cit., 140.

122 Murphy, op cit., 294.

123 B. Müller-Hill, "Truth, Justice and Genetics," in Perspectives in Biology and Medicine, 43:4 (2000), 578; Wolpe, op cit., 218. 
"the eternal and intrinsic badness of human nature" whereas the low scorers had much greater confidence in the innate potentialities of the human race..$^{124}$ Among the high scorers on the ethnocentrism scale, the suspicion of utopian theories was also salient ("one has to be "realistic") and so was the tendency to equal communism with the Stalinist Regime and even with plain war ${ }^{125}$ — which nowadays should be quite prevalent in view of the influence of authoritarian editors. Despite anthropological proof that Hobbes natural man is remarkably missing in the least civilized men, ${ }^{126}$ the psychiatric discourse has fervently maintained the same misanthropic view of the human being it had 150 years ago. The psychopath might then ask: why should I try to change when, in the end, I cannot get rid of my deviant nature? Besides, is it possible to have feelings of solidarity with creatures whose nature I do not share? To psychopaths who have been labeled as children (which is most likely to befall children of the socio-economically underprivileged, as both Smith and Sahlin observe ${ }^{127}$ ) an even more relevant question might be: why any "fellow-feeling" and "playing by the rules" in a society that has so radically reduced my possibilities to realize my potentialities? When the psychiatric misanthropy is as widespread and accepted in the cultural sphere as it is today, we should not be surprised if the psychopath, as one of Sade's sadistic characters, makes the following confession on his deathbed: "I only regret that I did not sufficiently recognize nature's omnipotence, and my only remorse concerns the mediocre use I have made of the faculties (criminal to you, all elementary to me) that nature gave me to serve its purposes." 128

In the view of man as fundamentally barbarian and of some men as more barbarian than the rest of us, unable to change, we find seeds of the psychopath's callous attitude towards his fellow beings. The lack of empathyor sympathy strictly speaking-is an inseparable aspect of biological reductionism; just as society does not care about the psychopath's childhood and his reactions to whatever he has been exposed to, the psychopath does not care about others' background and feelings. To psychiatry, and to the psychopath, people appear as things, as natural phenomena, as animals.

Only from the dominating view of psychopathy can we draw the conclusion that psychopathy is nothing but an exaggerated extension of widely accepted values, and not discontinuous with what is normal, as Jaspers once asserted. ${ }^{129}$ Since these values are so conspicuous in the psychiatric discourse we should perhaps ask whether it is any wonder that clinical treatment of psychopaths to date have uniformly failed? "The psychopath is not ill nor even seriously out of phase when functioning within a society where $b$ values are 1969), 696

124 T. W. Adorno, et al., The Authoritarian Personality (New York: Norton \& Company,

125 Ibid., 723

${ }^{126}$ Cf. Fromm, The Anatomy of Human Destructiveness, 136, for a summary of this research

${ }^{127}$ Sahlin, op cit., 64; Smith, op cit., 193.

${ }_{128}$ D. de Sade, Euvres 1 (Paris: Gallimard, 1990), 4.

129 Smith, op cit., 183. 
both practiced and legitimated in the marketplace," as Smith eloquently puts it; "insofar as the prevailing values of a society continue in the $b$ direction then the psychopath has indeed learned from experience and is an important source of moral agency for that society-is heavily socialized, not antisocial personality." 130

\section{Conclusion}

Not very surprisingly, psychopathy is primarily described as a biological form of deviation in the analyzed articles. Social aspects of psychopathy are mentioned; there is an "interplay" between nature and nurture, but the role of nurture seems to be limited to deciding what concrete expressions the inherited psychopathy assumes. Being a natural phenomenon, psychopathy is generally assessed to be untreatable. The only way to handle psychopathy is to spot it and stigmatize the individual as early as possible. After that, it remains unclear what ought to be done: either lock them up or try to drill or medicate the behavior away.

Even if psychopathy is biological and inherited according to the dominating discourse, parents' consciences are never burdened with guilt of any kind. Psychopathy is the result of neither family nor society; it is a natural disaster for which no one can be blamed. The psychopath is an animal, unable to apprehend and accept conventional values, but still appearing to be as human as anyone else. Hence, psychopathy is not even a tragedy; it is simply a fact of life that the Enlightenment project (i.e. technology) will eventually wipe out if people only learn to put enough faith into "evidence-based" sciences such as genetics and neurology.

In comparison with the sociological and psychoanalytical theories mentioned above, striving for power is, in the popularized version of the psychiatric discourse, not the cause for aggressiveness but means to stop aggressiveness from disseminating. This power glorification is, just as the biologist reduction of psychopaths to animals, formulated in philanthropic terms. Since psychopaths lack fundamental qualities that characterize the human being, they only constitute a threat to humanity and are fully comparable with an earthquake. If, however, the psychopath is a human being, the psychiatric discourse appears in a different light. The authoritarianism and mutilating essentialism that psychiatry then could be charged for, differ radically from the values psychiatry is supposed to defend, and prove that the psychopath is not antisocial but, on the contrary, extremely socialized and in tune with the values of his society.

It is worth noting that we have been able to draw this conclusion entirely from the study of how psychopathy is treated in the dominating media discourse. No parallels have been drawn between individual aggression and governmental aggression. We have not derived psychopathy from the alienating production of capitalism or its reifying competition that, thanks to

130 Ibid., 193 
our system of education, is particularly prevalent at the individual level. The fact that the occurrence of antisocial personality disorders (including both sociopathy and psychopathy) is about ten times higher in US than in Taiwan, ${ }^{131}$ has not been discussed. Nor the fact that psychopaths stand out as heroes during wartimes. No parallel has either been drawn to Machiavellian management literature where psychopathic traits are described as virtues. This seems to us a virtue of our account. Future research in the field of psychopathy should consider these and similar social phenomena more carefully than what has been done here, and notably, as we have tried to prove, in the dominating discourse.

Department of Sociology, Uppsala University, Sweden

\section{References}

Adorno, T. W. \& Horkheimer, M., Dialectic of Enlightenment (Stanford: Standford University Press, 2002).

Adorno, T. W., et al., The Authoritarian Personality (New York: Norton \& Company, (1969).

Bakhtin, M. M., "Speech Genres and Other Late Essays," in The Discourse Reader (Surrey: Routledge, 1999).

Balzac, Honoré de, Illusions Perdues (Bourges: Garnier Frères, 1967).

Bauman, Z., Modernity and the Holocaust (Cambridge: Polity, 1989).

Beck, U., Risk Society: Towards a New Modernity (London: Sage, 1992).

Birmingham Post, 040911.

Borås Tidning, 040418.

Brodwin, P., 2002) "Genetics, Identity and the Anthropology of Essentialism," in Anthropological Quarterly, 75:2 (2002), 323-330.

Camus, A., 2003 Caligula suivi de Le Malentendu (Saint-Amand: Folio, 2003).

Dagens Nyheter, 031015, 040217, 040310, 040507, 060104.

Daily Telegraph, 050525.

Economist Newspaper, 050528.

Evening Standard, 040112.

Expressen, 030403.

Fairclough, N., "Discourse and Text: Linguistic and Intertextual Analysis within Discourse Analysis," in The Discourse Reader (Surrey: Routledge, 1999).

Fairclough, N., Media Discourse (London: Edward Arnold, 1995).

Foucault, M., Madness and Civilization (New York: Vintage Books, 1973).

Fromm, E., Escape from Freedom (New York: Owl Books, 1941). The Anatomy of Human Destructiveness (New York: Holt, Rinehart and Winston, 1973).

The Sane Society (New York: Owl Books, 1990).

131 Stout, op cit., 136. 
Gough, H. G., "A Sociological Theory of Psychopathy," in The American Journal of Sociology, 53:5 (1948), 359-366.

Guardian, 050403.

Hare, R. D., "The Revised Psychopathy Checklist: Descriptive Statistics, Reliability, and Factor Structure," in Psychological Assessment, 2 (1990), 338-341. 1970).

Psychopathy: Theory and Research (New York: John Wiley \& Sons, Without Conscience: the Disturbing World of the Psychopaths (New York: Guilford, 1995).

Helsingborgs Dagblad, 030918.

Hobbes, T., Leviathan. (St. Ives: Penguin Classics, 1968).

Hogg, M. A. \& Vaughan, G. M., Social Psychology (Gosport: Pearson, 2005).

Holmberg, T., Vetenskap på Gränsen (Malmö: Arkiv, 2005).

Independent, 040112.

Kärfve, E., Hjärnspöken: Damp och Hotet mot Folkhälsan (Stockholm: Symposion, 2000).

Lukács, G., Förnuftets Banemän (Lund: Arkiv förlag, 1985).

Marcuse, H., Negations: Essays in Critical Theory (London: Allen Lane, 1969). One-Dimensional Man (Boston: Beacon Press, 1991).

McCann-Mortimer, P.; Augoustinos, M.; LeCouteur A, "'Race' and the Human Genome Project: Constructions of Scientific Legitimacy," in Discourse \& Society, 15:4 (2004), 409-432.

Mills, S., Discourse (London: Routledge, 1997).

Müller-Hill, B., "Truth, Justice and Genetics," in Perspectives in Biology and Medicine, 43:4 (2000), 577-583.

Murphy, J. G., "Moral Death: A Kantian Essay on Psychopathy," in Ethics, 82:4 (1972), 284-298.

Nelkin, D. \& Lindee, M. S., The DNA Mystique (New York: W. H. Freeman and Company, 1995).

North Devon Journal, 051013.

Observer, 051120.

Orwell, G., Nineteen Eighty-Four (Suffolk: Penguin, 1972).

Paulsen, R., Explaining Psychopathy (University of Stockholm: Department of Sociology, 2005).

Pollack, E., En Studie i Medier och Brott (Stockholm: JMK, 2001).

Radden, J., "Commentary on 'Psychopathy, Other-Regarding Moral Beliefs, and Responsibility"," in Philosophy, Psychiatry \& Psychology, Vol. 3, No. 4 (1996), 287-289.

Rickert, J., "The Fromm-Marcuse Debate Revisited," in Theory and Society, Vol. 15, No 3 (1986), 351-400.

Rifkin, J., The Biotech Century (London: Victor Gollancz, 1998).

Sade, D. de, Euvres 1 (Paris: Gallimard, 1990).

Sahlin, I., "Psykopatibegreppets Renässans," in Ord och Bild, 4-5 (2002), 61-76.

Smith, R. J., "The Psychopath as a Moral Agent," in Philosophy and Phenomenological Research, 45:2 (1984), 177-193. 


\section{MEDIATED PSYCHOPATHY}

Stout, M., The Sociopath Next Door (New York: Broadway Books, 2005).

Sunday Times, 040621.

Svenska Dagbladet, 030919, 030929, 040331.

von Heijne, G. \& Israel, J., Skapelsens Herre eller Genernas Slav? (Stockholm: Ordfront, 1985).

Weber, M., Den Protestantiska Etiken och Kapitalismens Anda (Lund: Argos, 1978).

Werlinder, H., Psychopathy: A History of the Concept (Uppsala: Almqvist \& Wiksell, 1978).

Wodak, R. ed., Methods of Critical Discourse Analysis (London: Sage, 2002).

Wolpe, P. R., "If I Am Only My Genes, What Am I? Genetic Essentialism and a Jewish Response," in Kennedy Institute of Ethics Journal, 7:3 (1997), 213230. 